ÉGYPTE

monde arabe

\section{Égypte/Monde arabe}

$34 \mid 1998$

Droits d'Égypte : histoire et sociologie

\title{
Human rights, the rule of law, and the construction of tradition
}

The Egyptian Supreme Administrative Court and Female Circumcision (appeal no. 5257/43, 28 Dec. 1997)

\section{Kilian Bälz}

\section{OpenEdition}

\section{Journals}

Édition électronique

URL : https://journals.openedition.org/ema/1511

DOI : 10.4000/ema.1511

ISSN : 2090-7273

Éditeur

CEDEJ - Centre d'études et de documentation économiques juridiques et sociales

Édition imprimée

Date de publication : 31 décembre 1998

Pagination : 141-153

ISSN : 1110-5097

Référence électronique

Kilian Bälz, "Human rights, the rule of law, and the construction of tradition », Égypte/Monde arabe [En ligne], 34 | 1998, mis en ligne le 08 juillet 2008, consulté le 07 juillet 2022. URL : http:// journals.openedition.org/ema/1511; DOI : https://doi.org/10.4000/ema.1511

Ce document a été généré automatiquement le 7 juillet 2022.

Tous droits réservés 


\section{Human rights, the rule of law, and the construction of tradition}

The Egyptian Supreme Administrative Court and Female Circumcision (appeal no. 5257/43, 28 Dec. 1997)

\section{Kilian Bälz}

1 Few issues have generated a greater body of literature in recent years than Islam and human rights. ${ }^{1}$ Both increasing human rights awareness throughout the Arab world, and human rights rhetoric entering international politics have fuelled the debate on whether "Islam » is incompatible with, or at least hampers, the development of "human rights» as defined in international conventions. ${ }^{2}$ While some studies emphasize areas of conflict between « Western » and « Islamic » conceptions of human rights (e.g. Mayer, 1991), others stress the discursive character of the Arab human rights debate and underline the diversity of opinions produced by both Islamist and secular thinkers (e.g. Müller, 1996). The majority of studies, nevertheless, have two features in common. First, "culture " is isolated as a prominent determinant in the development of human rights. The starting point is the concept of human rights as a product of Western civilization. Human rights issues in Arab and Islamic societies are consequently treated as questions of « culture-based resistance » to the « reception » of Western legal principles. Second, in examining the alleged incompatibilities, most studies focus on Islamic legal writings dealing with the issue from a more or less theoretical perspective, at times complemented by selected constitutional documents.

2 This paper, in contrast, takes a different approach. Drawing on a recent Egyptian case regarding female circumcision, the question of «Islam and human rights " will be examined in the light of judicial practice. Choosing the judicial implementation of human rights as a starting point, moreover, allows one to reconsider the role assigned to « culture » in this context. 


\section{Human rights and the rule of law}

3 The judicial implementation of human rights cannot be divorced from the concept of the rule of law, the idea that the ruler is subject to the law and controlled through judicial procedure. In Egypt, this concept is enshrined in Article 64 of the 1971 Constitution, which states : "The rule of law is the basis of rule in the state (siyâdat alqânûn asâs al-hukm fi-l-dawla). »

4 The « supremacy of law » embodied in Article 64 of the Egyptian Constitution is based on a long-standing tradition (Brown, 1996; Ziadeh, 1968). The origins of modern administrative justice in Egypt can be traced back to the 19 th century. Moreover, the Egyptian Supreme Administrative Court (al-mahkama al-idâriyya al-'ulyâ), established in 1946, successfully claimed the right to constitutional review as early as 1948 (Hill, 1993 ; 'Azîza al-Sharîf, 1990). The Egyptian Supreme Constitutional Court (al-mahkama aldustûriyya al-'ulyâ), established in 1979, represents a powerful judicial body, widely respected for protecting the rule of law within a rather unfavorable political environment (Brown, 1997 : 102-107).

Both the Egyptian Administrative Court and the Supreme Constitutional Court have produced remarkable case laws covering a wide variety of human rights issues (alSharîf, 1990 ; el-Morr, 1993; Boyle and Sherif, 1996). In numerical terms, however, influence of Islamic law on the judicial implementation of human rights has, in Egyptian practice, been rather minimal ; the vast body of literature on «Islam and human rights" is not really related to the practical significance of the issue. Nevertheless, in some instances Islamic law may come into play, particularly with respect to issues of freedom of expression and religion ${ }^{3}$ as well as gender equality. Another issue is female circumcision, also known as female genital mutilation (FGM).

\section{The case of female circumcision}

6 Female circumcision ${ }^{4}(k h i t a ̂ n ~ a l-i n a ̂ t h)$ has been at the heart of the Islam-human rights controversy in Egypt in recent years. This custom of pre-Islamic origin, practiced in the Nile valley in Pharaonic times, was later incorporated in the body of Islamic figh, and at least by some fuqahâ' - explicitly sanctioned in Islamic terms (cf. Berkey, 1996). It is still widely practiced in Egypt today. A recent study holds that $97 \%$ of all Egyptian girls are subjected to this operation, ${ }^{5}$ which, due to its severe effects on both physical and mental health, is termed by critiques a " mutilation in the name of Allah » (Aldeeb AbuSahlieh, 1994b) and considered a "traitement inhumainet dégradant», an inhuman and degrading treatment (Jaillardon, 1997 :338). Female circumcision, therefore, has been among the core issues raised by Egyptian and international human rights organizations ${ }^{6}$. The American broadcasting channel CNN covered the issue on the occasion of the UN Conference on Population and Development in 1994. This, along with the death of a 14-year-old girl while a physician was performing the operation in 1996, once more fuelled controversy over the legitimacy of this custom, whose proponents argue is prescribed by Islam.

7 In July 1996, however, the Egyptian Minister of Health promulgated a decree (no. 261/1996) which provides :

Art. 1. Performing the operation of female circumcision ('amaliyyat khitân al-inâth) is

forbidden both in hospitals and public or private clinics, other than in cases of 
illness, which, upon request of the responsible physician, must be approved by the director of the gynaecological department of the hospital.

Art. 2. Performing the operation (of female circumcision) by non-physicians is a crime which is subject to punishment according to the laws and ordinances in force.

8 Through this decree, female circumcision was prohibited. Even though the 1996 decree was not the first attempt to regulate the issue, and previous legislation was everything but effective, ${ }^{7}$ the legislative measure put female circumcision once more on the agenda of public debate. While most human rights organizations cautiously welcomed the decree as a step towards eradicating a cruel and humiliating custom, Islamists tended to dismiss the decree, arguing it was contrary « to Islam and Islamic teachings. »

The decree, moreover, was instantly attacked in the Cairo Administrative Court. The plaintiffs, lead by Islamist Shaykh Yûsif al-Badrî, claimed that the decree was void as it violated, inter alia, the " principles of Islamic law » mentioned as « the major source of legislation » in Article 2 of the Egyptian Constitution. ${ }^{9}$ They stated that Islamic fuqahâ agreed on the legitimacy of female circumcision and that the worldly ruler (hâkim), moreover, may not impose any restrictions upon what is «allowed through a textual provision (mubâh bil-nass) » or what is « compulsory (wâjib) or recommended (mandûb)" under Islamic law, as this represents « a command of the divine legislator (amran min alshâri), which may not be opposed.»

10 The Administrative Court ruled in favor of the plaintiffs on 24 June $1996 .{ }^{10}$ The Minister of Health, however, appealed to the Supreme Administrative Court, which, in turn, waved the previous judgment on 28 December 1997. The ruling of the Supreme Administrative Court, meandering at times, develops around three key issues :

1. Are the plaintiffs entitled to the action, in other words: who has the right to intervene in case a legislative enactment violates the precepts of the Islamic sharî'a?

2. To what extent is the legislature bound by the «principles of the Islamic shari'a» mentioned in Article 2 of the Constitution? In other words: may a custom sanctioned through reference to Islamic law be banned by issuing a ministerial decree?

3. How does female circumcision relate to the right to bodily integrity? In other words : is there a legal basis which can justify the mutilation of female genitals?

11 A closer look at legal reasoning in the judgment puts the question of «culture-based resistance to rights " in a somewhat different light. Here, one can isolate two complementary tendencies. On the one hand, the Court readily allows legislative enactments to be challenged on grounds of violating the "principles of the Islamic shari'a» mentioned in Article 2 of the Constitution. On the other hand, however, the Court reserves the right to determine the substance of these principles. Through judicial review, based on «the principles of the Islamic shari'a, » the Court establishes itself in the end as the competent authority for the definition of « customs » recognized as « Islamic ».

\section{To raise an action - the right of every Muslim ?}

The question of who is entitled to an action has troubled Egyptian courts considerably in recent years, particularly due to the increasing number of so called hisba actions : hisba, the Islamic duty to "promote good and prevent evil » developed into a legal device which provides third parties with a legal standing whenever « the rights of God 
(huqûq Allah) »are infringed, understood to include all matters related to " public policy or the Islamic Umma in general. » This allowed submitting allegedly "un-islamic » behavior of whatever kind, to judicial scrutiny (cf. Bälz, 1998). The most prominent cases based on the hisba principle are the "Abu Zayd case " ${ }^{11}$ and the legal battle which followed the release of Youssef Chahine's film Al-Muhâjir ${ }^{12}$ Through an amendment of both the law of personal status and the Code of Civil and Commercial Procedures in 1996, however, this kind of popular action was abolished. ${ }^{13}$

When discussing the present case, the Court therefore consciously avoided any reference to the Islamic duty to " promote good and to prevent evil, » and, moreover, explicitly stated that the present action did not represent a hisba action, but was based on established principles of Egyptian administrative law. Article 12 paragraph 1 of Law no. 47/1972 regulating, inter alia, procedures in the administrative courts provides that " claims will not be heard» unless raised by somebody who has a "personal interest (maslaha shakhsiyya) in them. » In the case of challenging an administrative decree in the administrative courts, however, the Court held that whoever holds a " particular legal position (hâla qânûniyya khâssa) » has a " personal interesf in the action.

This approach is consistent with established principles of Egyptian procedural law. While in civil and commercial disputes the requirement of «interest in an action » is commonly understood to require the plaintiff to pursue a personal right, in administrative disputes, the scope of «interesf is defined in a much wider sense. An action contesting an administrative act (qarâr idârî) does not primarily serve the function of enforcing a private right, but is a recours pour excès de pouvoir, a means to control the legality of administrative acts ('Abdallah, $1996: 483-487$ ).

In the present case, that the plaintiffs were «Egyptian Muslims » was enough for the Court to provide them with a legal standing :

Whoever believes in Islam and who holds the opinion that the correct judgement according to Islamic law regarding female circumcision follows from his belief, in the sense that this is something commanded by the shari'a, whether considered part of Islamic tradition (sunan al-Islam) or as a kind of good deed (makrama) for women, has a personal interest in raising an action.

Through this approach, the Court paved the way to scrutinize whether the decree enacted by the Minister of Health was consistent with the "principles of the Islamic shari'a » mentioned in Article 2 of the Constitution.

\section{The principles of the Islamic Sharia as the major source of legislation}

17 The case under discussion is by far not the only case where a legislative enactment was challenged on grounds of violating « the principles of the Islamic shari'a » mentioned in Article 2 of the Egyptian Constitution. Provisions of the civil and penal codes as well as provisions relating to divorce and custody in the law of personal status have been attacked on these grounds as well. When the constitutional provision was first enacted in 1971, and later amended in 1980, it caused a considerable amount of unrest. By now, however, the Egyptian Supreme Constitutional Court has developed firm principles regarding judicial review based on "the principles of the Islamic shari'a (cf. Dupret, 1997a ; Bälz, 1997b). 
In the present case, the Supreme Administrative Court summarizes these principles as follows :

The principles of the Islamic shari'a are the major source of legislation (tashri). This imposes a limitation curtailing both the legislative and executive power, through which they are obliged, in whatever laws or decrees they enact, to avoid provisions that may contradict the provisions of Islamic law which are definite in terms of their immutability and their meaning (al-ahkâm al-shar'iyya al-qat'iyya fi thubûtihâ wa dalâlatihâ). Because these principles...are not accessible to ijtihâd, since they represent the general principles and immutable sources of the Islamic shari'a, which are not open to interpretation and cannot be changed...it is (consequently) not permitted to deviate from them or to depart from their meaning. Whatever legislative enactment contravenes them must be declared null and void.

This, however, does not imply that the legislature is bound to a specific interpretation put forth by the fuqahâ'. In contrast to the immutable, general principles of the Islamic shari'a, there are rules which are open to interpretation. The Court continues:

The rules subject to interpretation (ahkâm zanniyya) are not stable in terms of their immutability and their meaning or in both respects. They belong to the realm of ijtihâd.... Their application is flexible and open to change according to time and clime, in order to ensure flexibility and dynamism, when coping with new developments in their various appearances, when regulating the matters of man (shu'ûn al-'ibâd) for the sake of protecting their legally recognized interests and putting the general aims of the shari'a into practice.

Consequently, in case there is no "definite " provision of Islamic law governing a particular matter, the legislature has the right to exercise ijtihâd, «independent reasoning ». It has both the duty and privilege to find an interpretation of its own which is consistent with the requirements of « time and clime».

21 Regarding the case under examination, the Court discusses female circumcision under Islamic law at length. Not mentioned in the Koran, this pre-Islamic custom is normally sanctioned by refering to various hadith material, including, in particular, the so-called Exciser's Narration. Umm 'Attiyya, who was known for performing the operation of female circumcision, was asked by the Prophet whether she still practiced her profession. When she confirmed this, the Prophet replied: «Cut slightly and do not overdo it, because it brings more radiance to the face and is more pleasant for the husband. »

Other hadith material invoked in this instance attributes to the Prophet sayings such as : "Circumcision (khitân) conforms to the sunna (tradition) for men and is makram (considered a good deed) for women" and "whoever turns to Islam must be circumcised."

23 However, modern scholars do not agree on the validity and the interpretation of the hâdith-s. The Court held that "there is no consensus (ijmâ) among the fuqahâ'" regarding female circumcision and explained : «Many of them (i.e. the fuqahâ) explicitly oppose this act (arguing that) the valid sunna does not require female circumcision. Whatever hadith material can be invoked in this respect is without exception "weak» (da'iff).... For this reason one cannot derive a clear and definite provision or legal ordinance from this source. This is the reason why there is disagreement (ikhtilâf) among the four schools of law (madhâhib) with respect to female circumcision. » 
24 As there is no "definite" provision of Islamic law governing female circumcision, regulating this issue is consequently at the legislature's discretion. The legislature must interpret the « immutable sources and general principles » of Islamic law in the light of contemporary social conditions in order to arrive at a regulation consistent with the requirements of «time and clime». This, moreover, allows the Court to introduce principles of international human rights law to its legal argumentation.

\section{Female circumcision and the right to bodily integrity}

The Court begins by defining the scope of bodily integrity (salâmat al-jism), here referring to the concept of intégrité corporelle: " Legal protection covers all parts of the body, whether outer or inner. " Moreover, "the human right (haqq al-insân) " to the protection of bodily integrity requires the following: " to protect the natural course of bodily functions", as well as "to safeguard all bodily parts as a whole and not to mutilate them " and «to avoid physical and psychological pains ». Any intrusion upon the right to bodily integrity requires a «legitimizing reason » (sabab al-ibâha /cause de justification).

Such a «legitimizing reason, » the Court held, does not exist in the case of female circumcision. Here, reasoning is based on arguments derived from both medical and penal law.

27 Article 1 of Law no. 415/1954 regulating the medical profession permits all Egyptians who are duly registered as physicians with the Ministry of Health and the Syndicate of the medical profession to practice the medical profession and to perform whatever medical treatment is appropriate. This provision also provides the legal basis for carrying out surgery. ${ }^{14}$ It does not, however, grant physicians the right to perform the operation of female circumcision. The Court held that "surgery » is only justified in the case of «illness. » Moreover, it has to be carried out with "the intention to heal». Female circumcision, in contrast, falls short of both these requirements. Such practice, therefore, cannot be considered «medical treatment " protected under the law. The Court also held that the provisions of the Egyptian Penal Code (Law no. 58/1937) do not provide a legal basis for female circumcision. The Penal Code deals in several instances with "justification on grounds of Islamic law, " providing that exercising a "right based on the sharî' $a$ » does not constitute a criminal offence. ${ }^{15}$ Interpretation of these provisions is rather unclear. Nevertheless, the preferred opinion holds that they are not meant to legalize whatever may be allowed under Islamic law, but were included for historical reasons and have always been limited in application. ${ }^{16} \mathrm{Be}$ this as it may, they cannot be invoked in order to legalize female circumcision. The Court held:

Female circumcision does not represent a right to be exercised by anyone over anyone else, as it is neither a duty (fard) nor an obligation (wâjib) according to its ruling (hukm) under Islamic law. In contrast, the majority of the medical profession considers...it a detrimental act to women, inflicting substantial damage which cannot be permitted except for the sake of medical treatment. And according to Islamic jurisprudence and law (fighan wa shar'an) there is the firm principle : lâ darar wa lâ dirâr.

Là darar wa là dirâr, which translates roughly as "no damage and no infliction of damage, " is a principle invoked in numerous instances in Islamic law. Commonly understood as a general rule «not to inflict harm,» its precise content, however, is hard to define. In the present context, the Court refers to this principle in order to 
support the banning of female circumcision. The arguments once put forth by the plaintiffs are herewith reversed: the "principles of the Islamic shari' $a$, originally invoked in order to challenge the ministerial decree, ultimately requires the banning of female circumcision.

\section{The rule of law and the construction of tradition} consist of ancient, presupposed rules, but often were «fabricated» by the modern judiciary. African customary law, to a large extent, is a historical construct of the colonial period, which, shaped within the framework of colonial justice, then served as the basis for the formation of the new national legal systems in the post-colonial period (Snyder, 1981; Chanock, 1985 ; Moore, 1986).

This paradigm, developed in the African context, cannot be transferred without qualification to the context at hand. Nevertheless, both the "fabrication » of African customary law and the case under discussion share one important feature. In both instances, legal tradition does not provide a body of stable, presupposed rules, but rather a point of reference or a réservoir (Dupret, 1997b), upon which «traditional law » is constructed within the framework of the nation-state's modern judiciary.

31 The fact that reference to the Islamic legal tradition in contemporary human rights discourse is selective, and that the body of traditional figh allows for different interpretations, is widely acknowledged in the literature dealing with «Islam and human rights. $\aleph^{17} \mathrm{As}$ the case under discussion exemplifies, however, investigation should not be limited to various opinions produced within scholarly discourse, but should also focus on the process through which legal traditions are constructed and defined when put into practice.

In Egypt, this process of constructing legal tradition is closely connected with the rule of law. Judicial review does not only allow the individual to challenge state-enacted legislation in the courts on the grounds that it contravenes the "principles of the Islamic sharî' $a$ but, vice versa, enables the nation-state's modem judiciary to construct an officially sanctioned interpretation of the body of Islamic law. Brown emphasizes that the rule of law in Egypt does not only serve to protect citizen's rights vis-à-vis the state, but also represents a means of control, whose purpose it is « to provide support for the officially sanctioned order..., constructed as an integral part of an effort to build a stronger, more effective, more centralized and more intrusive state» $(1997: 237)$. This finding also holds true for the context at hand, where the interpretation of " customs » deemed «Islamic » is defined through the nation-state's modem judiciary. The constitutional provision elevating " the principles of the Islamic sharî' $a$ " to " the major source of legislation" does not only allow for judicial review on the basis of Islamic legal principles - considering the way this constitutional provision is put into practice - but also provides the nation-state's judiciary with the authority to prescribe a « legally acknowledged » reading of the traditional body of figh.

As for the question of "Islam and human rights", the paradigm of "culture " consequently does not help to explain contemporary developments, as long as "culture" and "tradition" are considered to belong to a both a timeless and immutable past. As the case under discussion exemplifies, "Islamic traditions "

Égypte/Monde arabe, 34 | 1998 
invoked in human rights litigation have to be examined as a construct of the modern judiciary. Whatever shortcomings there are, they cannot be simply attributed to the "cultural background " of «traditional sharîa law. " On the contrary, they are the product of the modem judiciary operating within the rule of law.

\section{BIBLIOGRAPHIE}

'Abdallah, 'Abd al-Ghanî Basyûnî, 1996, al-Qadâ'al-idârî, Alexandria : Munshâ'at al-Ma'ârif. Aldeeb Abu-Sahlieh, Sami A. :

- 1994a, Les Musulmans face aux droits de l'homme : religion, droit et politique. Étude et documents, Bochum : Verlag Dr. Dieter Winkler.

- 1994b, To Mutilate in the Name of Jehovah or Allah : Legitimation of Male and Female Circumcision », Middle East Research Associates, Occasional Paper no. 21.

Bâlz, Kilian :

- 1997a, « Submitting Faith to Judicial Scrutiny through the Family Trial : The Abu Zayd Case, » Die Welt des Islams $37: 135-155$.

-1997b, « Islamisches Recht, staatliche Rechtsetzung und verfassungsgerichtsliche Kontrolle. Der âgyptische Verfassungsgerichtshof und der Schleier in staatlichen Schulen, » Zeitschrift fur auslàndisches ôffentliches Recht und Völkerrecht 57 :229-242.

-1998, « Die PopularWage zur Verteidigung der Rechte Gottes : hisba im heutigen Aegypten, » Verfassung und Recht in Clbersee $31: 60-69$.

Berkey, Jonathan P., 1996, « Circumcision Circumscribed : Female Excision and 'Cultural Accomodation in the Medieval Near East, » InternationalJournal of Middle East Studies $28: 19 \mathrm{ff}$.

Bernard-Maugiron, Nathalie, 1997, « Anatomie d'une affaire égyptienne. Le procès de L'Emigréde Youssef Chahine, » in : G. Boetsch/B. Dupret/J.N. Ferrié (eds.), Droits et sociétés dans le monde arabe, Aix-en-Provence : Presses de l'Université d'Aix-Marseille : 167-192.

Boyle, Kevin and Adel, Omar Sherif eds., 1996, Human Rights and Democracy-The Role of the Supreme Constitutional Court of Egypt, London/Den Haag/Boston : Kluwer Law International.

Brown, Nathan J., 1997, TheRuleofLawintheArab World : Courts in Egypt and the Gulf, Cambridge : Cambridge University Press.

Cairo Papers Annual Symposium, 1994, « Human Rights : Egypt and the Arab World", Cairo Papers in Social Science 17, no. 3.

Chanock, Martin, 1985, Law, Custom and Social Order : The Colonial Experience in Malawi and Zambia, Cambridge : Cambridge University Press.

Dupret, Baudouin :

- 1997a, « À propos de la constitutionnalité de la sharî'a, » Islamic Law and Society 4 : $91 \mathrm{ff}$. 
- 1997b, « Inventing Sharia : Egyptian Judges and the Islamic Legal Repertoire, » Chr. Barrigar éd., Religion, Pluralism and Law : Studies in Global Perspective, Mc Gill Studies in Religion vol. 5.

Dupret, Baudouin and J.-N. Ferrié, 1997, « For intérieur et ordre public. Ou comment la problématique de l'Aufklärung peut permettre de décrire un débat égyptien, » in : B. Dupret, J.-N. Ferrié and G. Boetsch eds., Droits et sociétés dans la monde arabe, Aix-en-Provence : Presses de l'Université d'Aix-Marseille : 193-215.

Dwyer, Kevin, 1991, Arab Voices : The Human Rights Debate in the Middle East, Berkeley /Los Angeles/ London : University of California Press.

Hill, Enid, 1993, « Majlis al-Dawla : The Administrative Courts of Egypt and Administrative Law, » in : Chibli Mallat éd., Islam and Public Law, London/ Dordrecht/ Boston : Graham \&Trotman : $207 \mathrm{ff}$.

Husnî, Mahmûd Najîb, 1982, Sharh qânûn al-'uqûbât, 5 th éd., Cairo : Dâr al-nahda al-'arabiyya. Jaillardon, Edith, 1997, « L'éloignement forcé et les risques d'excision : À propos du jugement du Tribunal Administratif de Lyon du 12 juin $1996^{\circ}$, Revue universelle des droits de l'homme 9 : $337 \mathrm{ff}$.

Langley, Winston E., 1992, Human Rights : Sixty Major Global Instruments, Jefferson N.C./ London : McFarland \& Company.

Mayer, Ann Elizabeth, 1991, Islam and Human Rights : Tradition and Politics, Boulder : Westview Press.

el-Morr, 'Awad, 1993, The Supreme Constitutional Court of Egypt and the Protection of Human and Political Rights, » in Chibli Mallat éd., Islam and Public Law, London/Dordrecht/ Boston : Graham \& Trotman : 229-261.

Moore, Sally Falk, 1986, Social Facts and Fabrications : 'Customary Law' on Kilimanjaro, 1880-1980, Cambridge : Cambridge University Press.

Miiller, Lorenz, 1996, Islam und Menschenrechte, Hamburg : Deutsches Orient Institut.

al-Saghîr, Jamîl 'Abd al-Bâqî, 1995, Khitân al-inâth bayna al-ibâha wa-l-tahrîm, Cairo : Dâr al-nahda al-'arabiyya.

al-Sharîf, 'Azîza, 1990, al-Qadâ'al-dustûrîal-misrî, Cairo : Dâr al-nahda al-'arabiyya.

Snyder, Francis G., 1981, « Colonialism and Legal Form : The Creation of 'Customary Law' in Senegal, » Journal of Legal Pluralism 19 : 49-90.

Ziadeh, Farhat, 1968, Lawyers, the Rule of Law and Liberalism in modem Egypt, Stanford : Stanford U.P.

\section{NOTES}

1. E.g. Mayer (1991); Dwyer (1991); Aldeeb Abu-Sahlieh (1994a); Cairo Papers (1994); Müller (1996).

2. In particular, the Universal Declaration of Human Rights (1948), the International Covenant on Economic, Social, and Cultural Rights (1966) and the International Covenant on Civil and Political Rights (1966). For a comprehensive overview of international human rights instruments see, e.g., Langley (1992).

3. Cf., e.g., the case law discussed in Bälz (1997a : 148-151).

4. Al-mahkama al-idâriyya al-'ulyâ, Minister of Health v. Shaykh Yûsif al-Badrî et al., Appeal no. 527/43 (28 December 1997). Quotations are taken, unless otherwise indicated, from the 
aforementioned judgement. On the same day, the Court also rendered another judgement dealing with the same issue : Prime Minister and Minister of Health v. Muhammad Fawzî al-Haww et al., Appeals no. 5204/43; 5834/43; 6091/43 (28 December 1997).

5. Egyptian Demographic Health Survey (1996) as quoted in Middle East Times, 27 June 1997.

6. On 17 July 1997, moreover, the European Parliament passed a resolution condemming « the practice of female genital mutilation of whatever kind. »

7. Through decree no. 74/1959, female circumcision in government hospitals was banned (Article 2). Moreover, non-physicians (including midwives) were prohibited to perform the operation (Article 1,3). The decree was modified through a ministerial decree enacted on 19 October 1994 (al-Saghîr, 1995 : 7-8).

8. Cf., e.g., Middle East Times, 27 June 1997 («Judge rules in favor of Islamic lawyers, » 1 ) and 21 November 1997 ("Judges postpone circumcision trial», 5); Al-Ahrâm Hebdo, 11 June 1997 ( L'excision envers et contre tout », 5) and 4 February 1998 (« La blessure de la chasteté », 8).

9. As amended on 22 May 1980.

10. The Administrative Court discussed female circumcision under Islamic law at some length. In the end, however, it based its ruling on a rather technical argument. Article 1 law no. 415/1954, regulating the medical profession, permits « all Egyptians who are duly registered as physicians with the Ministry of Health and the Syndicate of the Medical Profession to practice as a physician and to perform surgery.» Physicians, moreover, are entitled «to carry out whatever medical treatment falls into their competence» including «the operation of male and female circumcision, as this is considered medical treatment. » The privilege of practicing the medical profession, the Court held, is granted by virtue of a duly promulgated law, and, therefore, can only be restricted by virtue of a duly promulgated law. It cannot be curtailed, therefore, through a ministerial decree.

11. For a detailed discussion cf. Dupret/Ferrié (1997); Bälz (1997a).

12. For a detained discussion cf. Bernard-Maugiron (1997).

13. Laws no. 3/1996 and 81/1996.

14. Under Egyptian penal law, surgery is considered a trespass on the person unless the patient consents and the physician performs the operation with the intention to heal (Husnî, 1982: 174-175).

15. The Penal Code contains the following provisions, both invoked by the plaintiffs: Article 7. The provisions of this law (i.e. the Penal Code) in no respect affect personal rights which are based on the shari'a. Article 60. The provisions of the penal code are not to be applied to all acts which are carried out in good faith of exercising a right granted according to the shari'a.

16. Article 7 of the 1937 Penal Code equals Article 1 of the 1883 Penal Code. The provision was included in the 1883 Penal Code in order to ease transition to the new, European-style penal regime. Article 60 equals a provision added to the 1883 Penal Code in 1904, which was included in order to legalize disciplinary power (Husnî, $1982: 162$ ).

17. This is stressed, for instance, both by Mayer (1991) and Mûller (1996), even though they draw fairly disparate conclusions.

\section{INDEX}

Mots-clés : excision, loi, tradition, droits de l'homme 
AUTEUR

KILIAN BÄLZ

University of Frankfort on the Main 